\title{
Sulphide-linked Nitrite Reductase from Thiobacillus denitrificans with Cytochrome Oxidase Activity: Purification and Properties
}

\author{
By VEENA SAWHNEY AND D. J. D. NICHOLAS \\ Department of Agricultural Biochemistry, Waite Agricultural Research Institute, \\ University of Adelaide, Glen Osmond 5064, South Australia
}

(Received 9 November 1977; revised 21 December 1977)

\begin{abstract}
A membrane-bound, sulphide-linked nitrite reductase from Thiobacillus denitrificans was solubilized and after further purification its properties were examined. The purified enzyme, mol. wt 120000 , contained cytochromes $c$ and $d$ in the ratio of $1: 1$. Both cytochromes were reduced by sulphide and re-oxidized with nitrite or air. Oxidation by nitrite resulted in the appearance of an absorption peak at $572 \mathrm{~nm}$. The kinetics of the reduction of the enzyme with sulphide indicated that cytochrome $c$ was reduced before cytochrome $d$. The redox potential of cytochrome $d$ was $22 \mathrm{mV}$ more positive than that of cytochrome $c$. Cytochromes $c$ and $d$ were dissociated from the purified enzyme by treatment with sodium dodecyl sulphate. The purified nitrite reductase also had cytochrome oxidase activity and both the activities were stimulated by cytochrome $c-551$ isolated from $T$. denitrificans. Reduced cytochrome $c-551$ was an effective electron donor for the purified enzyme with either nitrite or air as the terminal electron acceptor. Neither cytochrome $c-554$ (also isolated from $T$. denitrificans) nor mammalian cytochrome $c$ was effective as reductant for the enzyme. $\mathrm{NO}$ and $\mathrm{N}_{2} \mathrm{O}$ were identified as the products of nitrite reduction by the purified sulphidelinked nitrite reductase.
\end{abstract}

\section{INTRODUCTION}

Thiobacillus denitrificans, a facultative anaerobe, grows chemolithotrophically on thiosulphate by cleaving it to sulphide and sulphite with a thiol-requiring enzyme (Aminuddin, 1974; Aleem, 1977). The products, sulphide and sulphite, are oxidized to sulphate. Under anaerobic conditions, the oxidation of sulphide and sulphite is linked to the reduction of nitrite and nitrate respectively (Adams, Warnes \& Nicholas, 1971; Aminuddin \& Nicholas, 1973, 1974a). A sulphite-linked nitrate reductase has been partially purified and some of its properties described (Sawhney \& Nicholas, 1977). Peeters \& Aleem (1970) proposed that the oxidation of sulphide, either aerobically or anaerobically, was coupled to the respiratory chain at the flavin level. In crude extracts of $T$. denitrificans, Aminuddin \& Nicholas (1974a) have observed that cytochromes $c$ and $d$ are reduced by sulphide and re-oxidized by nitrite or air. However, the properties of this sulphide-linked nitrite reductase have not been determined.

In this paper the solubilization, purification and properties of a sulphide-linked nitrite reductase are described. The purified enzyme contains a cytochrome $c d$ complex which is resolved into two cytochromes by treatment with sodium dodecyl sulphate. A scheme for electron transfer from sulphide via cytochrome $c-551$ and cytochrome $c d$ to either nitrite or oxygen is presented. 


\section{METHODS}

Culture and harvest of the organism. Thiobacillus denitrificans (9547, NCIB strain AB5) was grown and harvested as described by Aminuddin \& Nicholas (1974b). The harvested cells were washed twice with $0.025 \mathrm{M}$-Tris/ $\mathrm{HCl}$ buffer, $\mathrm{pH} 7 \cdot 5$, to remove nitrite.

Preparation of acetone-dried cells. The washed cells, suspended in $0.025 \mathrm{M}$-Tris/ $\mathrm{HCl}$ buffer, $\mathrm{pH} 7.5(500 \mathrm{mg}$ wet $\mathrm{wt} \mathrm{ml}^{-1}$ ), were added slowly to 10 vol. cold acetone at $-15^{\circ} \mathrm{C}$ with continuous stirring. After $10 \mathrm{~min}$, the mixture was filtered quickly through a Buchner funnel using Whatman no. 41 paper. The cells, after washing twice with 3 vol. cold acetone, were dried under a stream of $\mathrm{N}_{2}$ at $4{ }^{\circ} \mathrm{C}$. They were further dried

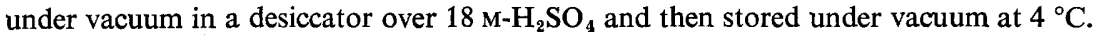

Preparation of cell-free extracts. The acetone-dried cells were ground to a fine powder in a pestle and mortar and suspended $(10 \%, \mathrm{w} / \mathrm{v})$ in $0.025 \mathrm{M}-\mathrm{Tris} / \mathrm{HCl}$ buffer, $\mathrm{pH} \mathrm{7.5}$. To the suspension, $5 \mathrm{mg}$ DNAase was added with continuous stirring for $4 \mathrm{~h}$ at $4{ }^{\circ} \mathrm{C}$. It was then filtered through two layers of cheesecloth and passed through a chilled French pressure cell at $140 \mathrm{MPa}$. The crude homogenate was centrifuged at $18000 \mathrm{~g}$ for $45 \mathrm{~min}$ and the supernatant fraction $\left(S_{18}\right)$ obtained was used for the purification of nitrite reductase.

Molecular weight of nitrite reductase. The molecular weight of the enzyme was determined by gel filtration through a Sephadex G-150 column $(2.5 \times 50 \mathrm{~cm})$ as described by Andrews (1964). The column was calibrated with a mixture of the following marker proteins of known molecular weights: $\gamma$-globulin $(160000)$, bovine serum albumin (68000), ovalbumin (45000) and myoglobin (17800). The void volume $\left(V_{0}\right)$ of the column was determined with Blue Dextran. The elution volume $\left(V_{\mathrm{e}}\right)$ of each protein and also of the nitrite reductase was measured. The molecular weight of the enzyme was calculated using the equation of Squire (1964):

$$
M^{\frac{1}{3}}=151\left[1 \cdot 47-\left(V_{\mathrm{e}} / V_{0}\right)^{\frac{1}{3}}\right]
$$

Estimation of copper. Purified nitrite reductase (1 ml samples containing $12.5 \mathrm{mg}$ protein) was dried in acid-washed test tubes by heating slowly over a Bunsen burner, and its copper content was determined by atomic absorption spectrometry according to the procedure of Nambiar (1976).

Midpoint potential. The difference in midpoint potential of cytochromes $c$ and $d$ was determined from the equilibrium constant for reduction of the enzyme by the following equation of Shimada \& Orii (1976):

$$
\begin{gathered}
\text { Equilibrium constant, } K=\frac{\left(c^{3+}\right)\left(d^{2+}\right)}{\left(c^{2+}\right)\left(d^{3+}\right)} \\
E_{\mathrm{m}}, \text { cyt. } d-E_{\mathrm{m}}, \text { cyt. } c=0.06 \log K
\end{gathered}
$$

Spectrophotometry. The absorption spectra of the samples were determined in a recording spectrophotometer (model MPs-50L; Shimadzu, Kyoto, Japan). For measurements under anaerobic conditions, Thunberg cuvettes $(1 \mathrm{~cm})$ were employed. The cuvettes were evacuated thoroughly and then flushed with $\mathrm{N}_{2}$; this procedure was repeated twice.

The concentration of the enzyme in purified preparations was calculated from its green haem $d$ content. A sample of the purified enzyme was made $25 \%(\mathrm{v} / \mathrm{v})$ and $0 \cdot 1 \mathrm{M}$ with respect to pyridine and $\mathrm{NaOH}$ respectively, and was dispensed into two $1 \mathrm{~cm}$ glass cuvettes. A crystal of $\mathrm{K}_{3} \mathrm{Fe}(\mathrm{CN})_{6}$ was added to the reference cuvette to oxidize the green haem. The $\Delta A_{618-650}$ between the reference and sample cuvettes was determined on a double-beam recording spectrophotometer and the amount of green haem was calculated using the absorption coefficient of $19 \cdot 6 \mathrm{~mm}^{-1} \mathrm{~cm}^{-1}$ (Newton, 1969).

Dissociation of cytochrome $c$ and d components. The purified nitrite reductase was treated with 1 to $1.5 \mathrm{mg}$ sodium dodecyl sulphate (SDS) (mg protein) ${ }^{-1}$ at $30^{\circ} \mathrm{C}$ for $30 \mathrm{~min}$ and then loaded on to a Sephadex G-100 column $(2.5 \times 45 \mathrm{~cm})$ which had been previously equilibrated with $0.025 \mathrm{M}$-Tris $/ \mathrm{HCl}$ buffer, $\mathrm{pH} 7.5$; the column was developed with the same buffer.

Assay of nitrite reductase. Nitrite reductase activity was assayed in Warburg flasks containing (final volume $1 \mathrm{ml}$ ): $0.025 \mathrm{M}$-Tris/ $\mathrm{HCl}$ buffer, $\mathrm{pH} 7.5 ; 1 \mu \mathrm{mol} \mathrm{NaNO}_{2}$; and $0.1 \mathrm{ml}$ enzyme. The flasks were evacuated and flushed with high-purity $\mathrm{N}_{2}$. After 5 min preincubation at $30^{\circ} \mathrm{C}, 2 \mu \mathrm{mol} \mathrm{Na}_{2} \mathrm{~S}$ (freshly prepared solution) was injected from an air-tight syringe into the side-arm of the flask through a Subaseal. The reaction was started by mixing the contents and terminated after $30 \mathrm{~min}$ by adding $1 \mathrm{ml} 10 \%(\mathrm{w} / \mathrm{v})$ zinc acetate in $10 \%(\mathrm{v} / \mathrm{v})$ ethanol. After centrifuging at $2000 \mathrm{~g}$ for $5 \mathrm{~min}$, nitrite was determined in a sample of the supernatant fraction by the method of Hewitt \& Nicholas (1964).

Assay of cytochrome oxidase. This activity was followed by measuring the rate of oxygen uptake in a Beckman oxygen electrode (model 39065) fitted with an adaptor box and recorder. Into the reaction vessel were dispensed $1.8 \mathrm{ml} 0.025 \mathrm{M}-\mathrm{Tris} / \mathrm{HCl}$ buffer, $\mathrm{pH} 7.5$, and $0.1 \mathrm{ml}$ purified enzyme, and these were 
Table 1. Purification of nitrite reductase

Total activity is expressed as $\mu \mathrm{mol} \mathrm{NO}_{2}{ }^{-}$reduced $(30 \mathrm{~min})^{-1}$, and specific activity as $\mu \mathrm{mol} \mathrm{NO}_{2}{ }^{-}$ reduced $(30 \mathrm{~min})^{-1}(\mathrm{mg} \text { protein })^{-1}$.

\section{Fraction}

$S_{18}$. Supernatant fraction after centrifuging the disrupted acetone-dried cells at $18000 \mathrm{~g}$

$\mathrm{S}_{100}$. Supernatant fraction after centrifuging $\mathrm{S}_{18}$ at $100000 \mathrm{~g}$ for $90 \mathrm{~min}$

$\left(\mathrm{NH}_{4}\right)_{2} \mathrm{SO}_{4}$ fraction. Precipitate of $\mathrm{S}_{100}$ obtained between 40 and $95 \%$ saturation $\left(\mathrm{NH}_{4}\right)_{2} \mathrm{SO}_{4}$, dissolved in $0.025 \mathrm{M}$-Tris $/ \mathrm{HCl}$ buffer, $\mathrm{pH} 7 \cdot 5$

Combined fractions from DEAE-cellulose column eluted with $0.025 \mathrm{M}$-Tris $/ \mathrm{HCl}$ buffer, pH $7 \cdot 5$

Combined fractions from Sephadex G-100 column eluted with $0.025 \mathrm{M}$-Tris $/ \mathrm{HCl}$ buffer, pH $7 \cdot 5$ for $45 \mathrm{~min}$

$\begin{array}{cccc}\begin{array}{c}\text { Total } \\ \text { activity } \\ 507.5\end{array} & \begin{array}{c}\text { Specific } \\ \text { activity } \\ 0.05\end{array} & \begin{array}{c}\% \text { Recovery } \\ \text { of activity }\end{array} & \begin{array}{c}\text { Relative } \\ \text { purity }\end{array} \\ 384.0 & 0.08 & 75 & 1 \\ 184.8 & 0.11 & 36 & 1.5 \\ 173.8 & 0.71 & 34 & 12 \cdot 8 \\ 132.3 & 1.12 & 26 & 20.4\end{array}$

equilibrated at $30^{\circ} \mathrm{C}$ for $5 \mathrm{~min}$. The electron donor (either sulphide or reduced $T$. denitrificans cytochrome $c$-551) was then injected from a microsyringe. The enzyme activity was expressed as nmol oxygen utilized $\min ^{-1}$ (mg protein) ${ }^{-1}$. Reduced cytochrome $c$ was prepared by adding excess $\mathrm{Na}_{2} \mathrm{~S}_{2} \mathrm{O}_{4}$ and then dialysing for $12 \mathrm{~h}$ against $0.025 \mathrm{M}$-Tris/ $\mathrm{HCl}$ buffer, $\mathrm{pH} 7 \cdot 5$, to remove the reductant.

Mass spectrometry. The gaseous products of purified nitrite reductase activity were identified in an A.E.I. MS-2 mass spectrometer using ${ }^{15} \mathrm{~N}$-labelled nitrite. The incubation mixture in Warburg flasks contained (final volume $1 \mathrm{ml}$ ): $10 \mu \mathrm{mol} \mathrm{Na}{ }^{15} \mathrm{NO}_{2}$ (27 atom \% excess); $0 \cdot 1 \mathrm{M}$-Tris/HCl buffer, $\mathrm{pH} 7 \cdot 5 ;$ and $0.2 \mathrm{ml}$ purified enzyme containing $2.5 \mathrm{mg}$ protein (specific activity 1.12 ). The flasks were evacuated with a vacuum pump and then flushed with $\mathrm{He}$. After $5 \mathrm{~min}$ preincubation at $30^{\circ} \mathrm{C}$, the reaction was started by injecting $10 \mu \mathrm{mol} \mathrm{Na} \mathrm{Na}_{2} \mathrm{~S}$ (freshly prepared solution) through a Subaseal fitted to the side-arm. The reaction was terminated by injecting $0.25 \mathrm{ml} 10 \mathrm{M}-\mathrm{KOH}$ into the reaction mixture. The gases formed were determined in the mass spectrometer.

Protein determination. The micro-biuret method of Itzhaki \& Gill (1964) was used for estimating protein with bovine serum albumin as a standard.

\section{RESULTS}

\section{Purification of nitrite reductase}

All procedures during purification of the enzyme were carried out at $4{ }^{\circ} \mathrm{C}$. The cell-free extract $\left(\mathrm{S}_{18}\right.$, Table 1$)$ was centrifuged at $100000 \mathrm{~g}$ for $90 \mathrm{~min}$. To this supernatant $\left(\mathrm{S}_{100}\right.$, Table 1) solid $\left(\mathrm{NH}_{4}\right)_{2} \mathrm{SO}_{4}$ was added gradually with stirring, and the precipitate obtained between 40 and $95 \%$ saturation was collected by centrifuging at $10000 \mathrm{~g}$ for $20 \mathrm{~min}$. The pellet

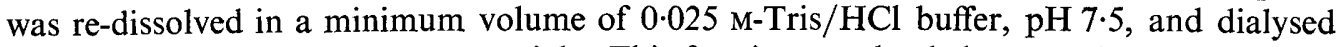
against double-distilled water overnight. This fraction was loaded on to a DEAE-cellulose column (DE32; $2.5 \times 26 \mathrm{~cm}$ ) previously equilibrated with $0.025 \mathrm{M}$-Tris $/ \mathrm{HCl}$ buffer, $\mathrm{pH} 7 \cdot 5$. Under these conditions, nitrite reductase was not adsorbed and was eluted with the equilibrating buffer in one column volume. Cytochrome $c-554$, which was retained on the column, was eluted with $0.025 \mathrm{M}$-Tris $/ \mathrm{HCl}, \mathrm{pH} 7 \cdot 5$, containing $0.5 \mathrm{M}-\mathrm{KCl}$. This cytochrome had absorption bands at 408 and $525 \mathrm{~nm}$ in its oxidized state and at 416, 524 and $554 \mathrm{~nm}$ when reduced with $\mathrm{Na}_{2} \mathrm{~S}_{2} \mathrm{O}_{4}$. The fractions containing nitrite reductase were pooled and concentrated by ultrafiltration under $\mathrm{N}_{2}$ using a PM-10 membrane (Amicon, Massachusetts, U.S.A.). The concentrated fraction was then loaded on to a Sephadex G-100 column $(2.5 \times 45 \mathrm{~cm})$ equilibrated with $0.025 \mathrm{M}$-Tris $/ \mathrm{HCl}$ buffer, $\mathrm{pH} 7 \cdot 5$. The same buffer was used to elute the sample and $3 \mathrm{ml}$ fractions were collected. Nitrite reductase was recovered after 


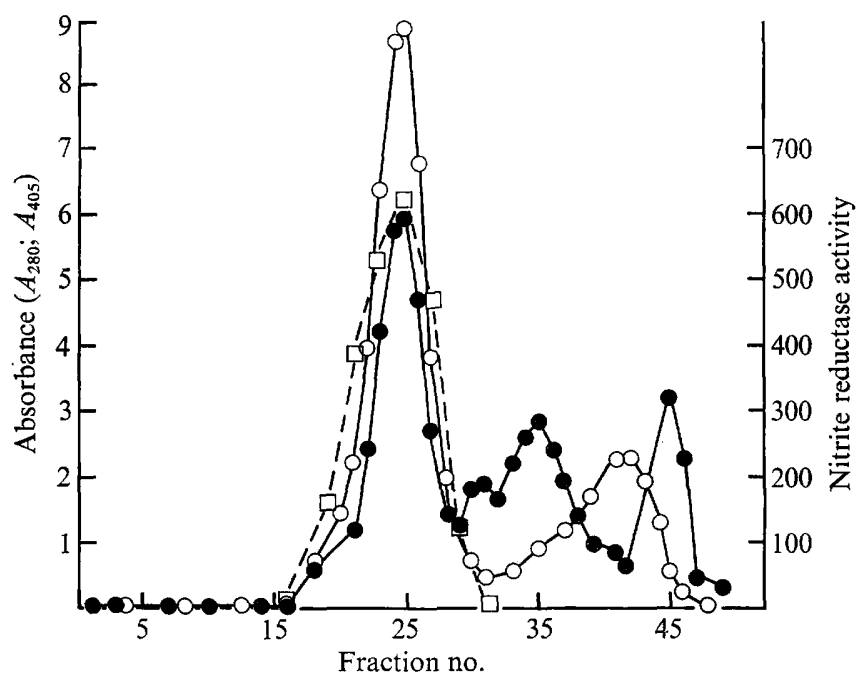

Fig. 1. Elution of nitrite reductase from Sephadex G-100. Combined fractions from a DEAEcellulose column were concentrated and loaded on to a Sephadex G-100 column equilibrated with $0.025 \mathrm{M}-$ Tris $/ \mathrm{HCl}$ buffer, $\mathrm{pH} 7 \cdot 5 . \odot, A_{280} ; \bigcirc, A_{405} ; \square$, nitrite reductase activity, expressed as nmol $\mathrm{NO}_{2}^{-}$reduced $(30 \mathrm{~min})^{-1}$.

the void volume in fractions 17 to 29 (Fig. 1); following fractions contained a cytochrome which had absorption maxima at 408 and $525 \mathrm{~nm}$ in the oxidized form and at 412,521 and $551 \mathrm{~nm}$ in the reduced form.

The purification procedure for nitrite reductase from $T$. denitrificans is summarized in Table 1.

\section{Some properties of the purified enzyme}

Absorption spectra. The oxidized enzyme had maxima at 405,525 and $645 \mathrm{~nm}$ and after reduction with $\mathrm{Na}_{2} \mathrm{~S}_{2} \mathrm{O}_{4}$, at $418,468,523,549$ to 554,615 and $695 \mathrm{~nm}$ (Fig. 2). When reduced anaerobically with sulphide, the physiological reductant for the enzyme, it had absorption bands at 418,462, 523, 549 to 554, 610 and 664 to $667 \mathrm{~nm}$ (Fig. $3 a$ ). The ratio of $A_{462} / A_{610}$ for the sulphide-reduced enzyme was three times greater than for the $\mathrm{Na}_{2} \mathrm{~S}_{2} \mathrm{O}_{4}$ reduced enzyme. The absorption bands at 418,523 and 549 to $554 \mathrm{~nm}$ are associated with cytochrome $c$ and those at 462,610 and 664 to $667 \mathrm{~nm}$ with cytochrome $d$.

The absorption spectrum of cytochrome $d$, but not that of cytochrome $c$, was $\mathrm{pH}$ dependent. On decreasing the $\mathrm{pH}$ from 8.0 to 5.5 , the ratio of $A_{462} / A_{610}$ in the reduced enzyme decreased from $1 \cdot 7$ to 0.42 .

Reaction with pyridine. The purified enzyme in alkaline pyridine and $\mathrm{Na}_{2} \mathrm{~S}_{2} \mathrm{O}_{4}$ had a sharp $\alpha$-band at $549 \mathrm{~nm}$ instead of a bifurcated peak at 549 to $554 \mathrm{~nm}$ and the ratio of reduced $\alpha /$ reduced $\beta$ increased from 1.0 to $2 \cdot 4$. The cytochrome $d$ was autoreducible in alkaline pyridine and the $\alpha$-peak, shifted to $620 \mathrm{~nm}$, was also sharpened considerably.

Reaction with cyanide. When the enzyme was reduced with sulphide in the presence of cyanide, the normal $\gamma$-peak of reduced cytochrome $d$ was abolished, two bands appeared at 443 and $482 \mathrm{~nm}$ and the $\alpha$-peak was shifted to $627 \mathrm{~nm}$. The absorbance at $523 \mathrm{~nm}$ was greatly decreased and the $554 \mathrm{~nm}$ component of the bifurcated $\alpha$-band became more pronounced.

Reaction with nitrite. When nitrite was added to the sulphide-reduced enzyme, cytochromes $c$ and $d$ both became oxidized (Fig. $3 b$ ). This effect was specific for nitrite since nitrate had no effect. On adding nitrite to the reduced enzyme, the absorption peak at $462 \mathrm{~nm}$ disappeared immediately followed by the one at $610 \mathrm{~nm}$ and subsequently the bands associated 


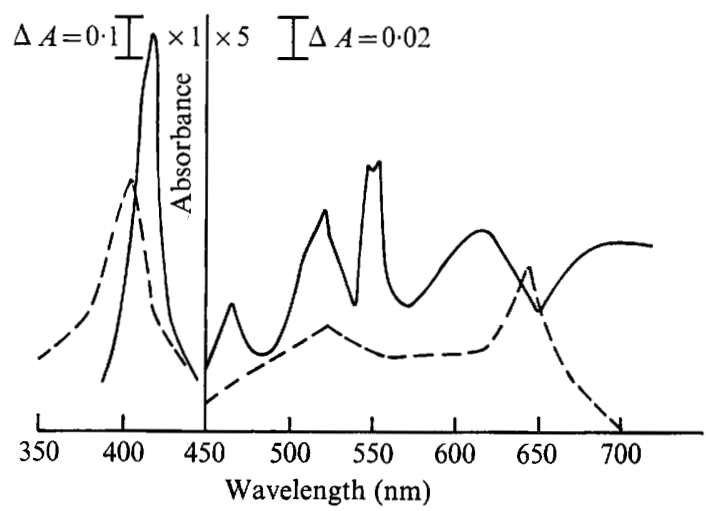

Fig. 2. Absorption spectra of purified nitrite reductase (specific activity $1 \cdot 12$ ):,$--- 6 \mu \mathrm{M}$-nitrite reductase in $43 \mathrm{~mm}$-Tris/ $\mathrm{HCl}$ buffer, $\mathrm{pH} 7 \cdot 5$; - , after reduction with $\mathrm{Na}_{2} \mathrm{~S}_{2} \mathrm{O}_{4}$.

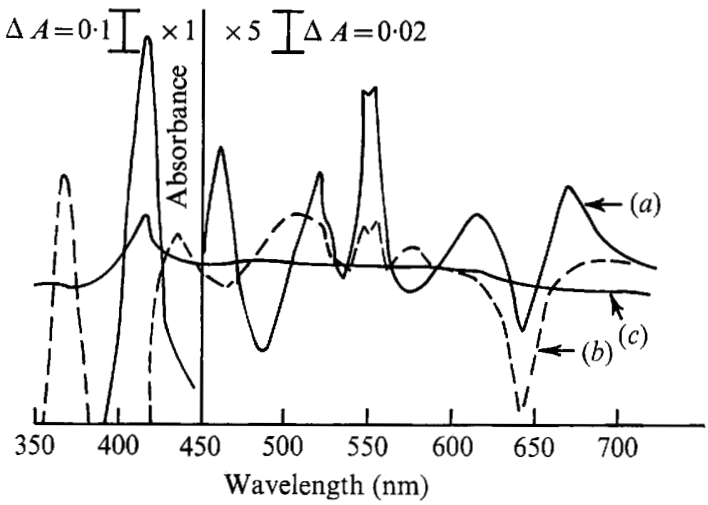

Fig. 3. Difference spectra of purified nitrite reductase (specific activity $1 \cdot 12):(a)$ reduced with sulphide; (b) after addition of $\mathrm{NO}_{2}^{-}$to the reduced enzyme. (a) $6 \mu$ M-nitrite reductase in $43 \mathrm{~mm}$ Tris/ $\mathrm{HCl}$ buffer, $\mathrm{pH} 7 \cdot 5$, (final volume $2 \mathrm{ml}$ ) was dispensed into a Thunberg cuvette and $5 \mathrm{mg}$ $\mathrm{Na}_{2} \mathrm{~S}$ was placed in the side-arm. The cuvette was evacuated and flushed twice with high-purity $\mathrm{N}_{2}$. The reaction was started by tipping $\mathrm{Na}_{2} \mathrm{~S}$ into the cuvette. After $10 \mathrm{~min}$, when the reduction was complete, the spectrum was recorded against a reference sample without $\mathrm{Na}_{2} \mathrm{~S}$. (b) Difference spectrum recorded $10 \mathrm{~min}$ after adding $0 \cdot 1 \mathrm{M}-\mathrm{NaNO}_{2}$ to $(a) .(c)$ No difference line.

\section{Table 2. Ratio of haem d to $c$ in the purified nitrite reductase}

The concentration of cytochrome $d$ was calculated as described in Methods, and that of cytochrome $c$ was estimated from the difference in absorption of the oxidized and reduced band at $550 \mathrm{~nm}$, using an absorption coefficient of $30 \cdot 2 \mathrm{~mm}^{-1} \mathrm{~cm}^{-1}$ (Horio et al., 1961).

$\begin{array}{cccc}\text { Preparation } & \text { Haem } c & \text { Haem } d & \text { Haem } d \\ \text { no. } & (\mu \mathrm{M}) & (\mu \mathrm{M}) & \text { Haem } c \\ 1 & 104 & 110 & 1.05 \\ 2 & 92 & 96 & 1.04\end{array}$

with oxidized cytochrome $c$ appeared. The oxidation of the cytochrome components of the enzyme was accompanied by the appearance of a peak at $572 \mathrm{~nm}$.

Cytochromes $c$ and $d$ were present in the ratio of $1: 1$ (Table 2). The sequence of reduction of cytochromes $c$ and $d$ on addition of sulphide to the enzyme was determined by monitoring the percentage reduction of these cytochromes at 554 and $610 \mathrm{~nm}$ respectively. As shown in Fig. 4, cytochrome $c$ was reduced to a greater extent than cytochrome $d$ during the initial 
Table 3. Comparison of nitrite reductase and cytochrome oxidase activities of purified nitrite reductase

The nitrite reductase and cytochrome oxidase activities of purified enzyme (specific activity 1.12) were determined as described in Methods with either $\mathrm{S}^{2-}$ or $\mathrm{Na}_{2} \mathrm{~S}_{2} \mathrm{O}_{4}$-reduced $T$. denitrificans cytochrome $c-551$ as electron donor. In one experiment in which $\mathbf{S}^{2-}$ was used as the reductant, the assay mixture also contained $T$. denitrificans cytochrome $c-551(2 \mu \mathrm{M})$. Nitrite reductase activity is expressed as nmol $\mathrm{NO}_{2}^{-}$reduced $\mathrm{min}^{-1}$ (mg protein) ${ }^{-1}$, and cytochrome oxidase activity as $\mathrm{nmol} \mathrm{O}_{2}$ utilized $\min ^{-1}(\mathrm{mg} \text { protein })^{-1}$.

$\begin{array}{llcc}\text { Electron donor } & \text { Addition to the assay mixture } & \begin{array}{c}\text { Nitrite } \\ \text { reductase } \\ \text { activity }\end{array} & \begin{array}{c}\text { Cytochrome } \\ \text { oxidase } \\ \text { activity }\end{array} \\ \begin{array}{l}\text { Sulphide }(2 \mu \mathrm{mol}) \\ \text { Sulphide }(2 \mu \mathrm{mol})\end{array} & \text { None } & 35 & 18 \\ \begin{array}{l}\text { Reduced cytochrome } c-551 \\ \begin{array}{l}(20 \mathrm{nmol}) \\ \text { Reduced cytochrome } c-551\end{array}\end{array} & \text { Cytochrome } c-551(2 \mu \mathrm{M}) & 107 & 45 \\ (53 \mathrm{nmol}) & \text { None } & 21 & 20 \\ & \text { None } & 59 & 53\end{array}$

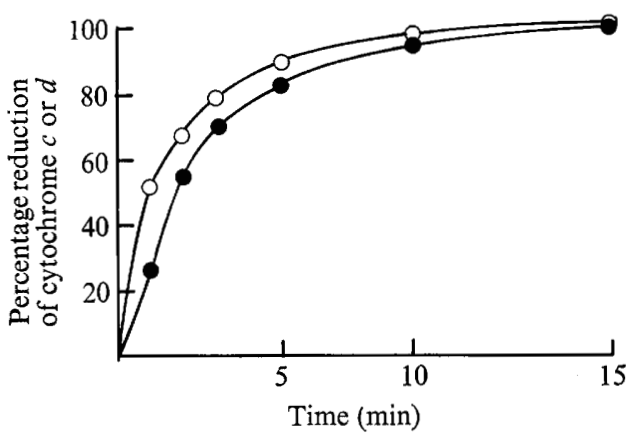

Fig. 4

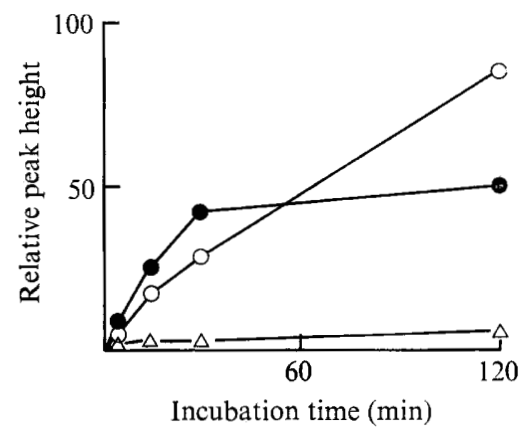

Fig. 5

Fig. 4. Sequence of reduction of cytochromes $c$ and $d$ of purified nitrite reductase. Details of the reaction mixture and experimental conditions were as described in the legend to Fig. 3 except that the rates of reduction of cytochromes $c$ and $d$ were recorded immediately after adding sulphide from the side-arm of the Thunberg cuvette. The percentage reduction was calculated on the basis of the maximum reduction of the cytochromes obtained, namely $2 \cdot 5 \mu \mathrm{M}$-cytochrome $c$ and $2 \cdot 3 \mu \mathrm{M}$ cytochrome $d . \bigcirc, \Delta A_{554} ; 0, \Delta A_{610}$.

Fig. 5. The nitrogenous gases produced from ${ }^{15} \mathrm{NO}_{2}{ }^{-}$by purified nitrite reductase. The reaction mixture (see Methods) was incubated for various times. Each reaction was terminated by adding $0.25 \mathrm{ml} 10 \mathrm{M}-\mathrm{KOH}$ and the ${ }^{15} \mathrm{~N}$-labelled gases thus formed were identified in a mass spectrometer: $\mathrm{O}, \mathrm{NO}(\operatorname{mass} 31) ; 0, \mathrm{~N}_{2} \mathrm{O}$ (mass 45$) ; \triangle, \mathrm{N}_{2}$ (mass 29 ).

stages of reduction. On adding nitrite to the reduced enzyme, cytochrome $d$ was oxidized more rapidly than cytochrome $c$.

The molecular weight of the nitrite reductase was found to be about 120000 as determined by gel filtration through Sephadex G-150. The difference in midpoint potential of cytochromes $d$ and $c$ was calculated from Fig. 4 as described in Methods. The redox potential of cytochrome $d$ was $22 \mathrm{mV}$ more positive than that of cytochrome $c$. The copper content of the purified nitrite reductase was less than $0.06 \mathrm{ng}$-atom $\mathrm{mg}^{-1}$.

Enzyme activity. The purified nitrite reductase also showed cytochrome oxidase activity since oxygen uptake was observed on adding sulphide (Table 3). Oxygen uptake and nitrite reduction increased threefold on adding $T$. denitrificans cytochrome $c$-551 to the reaction mixture. In contrast, $T$. denitrificans cytochrome $c-554$ and mammalian cytochrome $c$ had no effect. Reduced $T$. denitrificans cytochrome $c-551$ was an effective electron donor for both nitrite reduction and oxygen utilization; activity was proportional to the amount of cytochrome $c-551$ added. The stoicheiometry of the oxidation of cytochrome $c-551$ and 


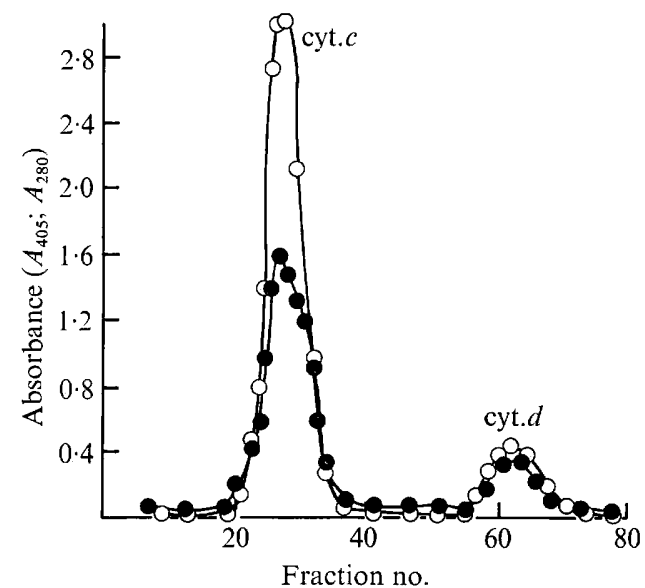

Fig. 6. Elution of cytochromes $c$ and $d$ on a Sephadex G-100 column. Purified nitrite reductase was treated with SDS at $30^{\circ} \mathrm{C}$ for $30 \mathrm{~min}$, loaded on to a Sephadex G-100 column and eluted with $0.025 \mathrm{M}$-Tris/ $\mathrm{HCl}$ buffer, $\mathrm{pH} 7.5$, at room temperature: $\mathrm{O}, A_{405} ; \boldsymbol{0}, A_{280}$.

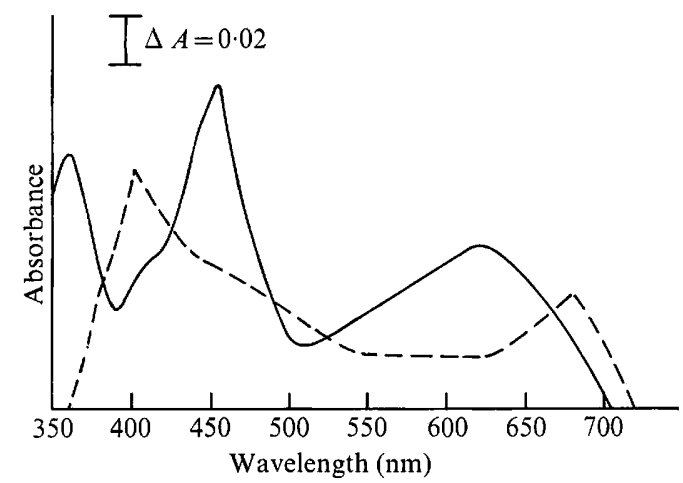

Fig. 7. Absorption spectra of cytochrome $d$, obtained after treatment of the purified nitrite reductase with SDS: - - oxidized; —-, reduced with $\mathrm{Na}_{2} \mathrm{~S}_{2} \mathrm{O}_{4}$.

nitrite reduction was $1: 1$ over the range 10 to $100 \mathrm{nmol}$. This bacterial cytochrome $c$ was much more effective than the mammalian cytochrome $c$ in reducing nitrite.

Products of nitrite reduction. From ${ }^{15} \mathrm{NO}_{2}^{-}$, the purified nitrite reductase produced both $\mathrm{NO}$ (mass 31) and $\mathrm{N}_{2} \mathrm{O}$ (mass 45) (Fig. 5). During the first 30 min of incubation $\mathrm{N}_{2} \mathrm{O}$ was formed in relatively larger amounts than NO.

Dissociation of cytochromes $c$ and $d$. Cytochromes $c$ and $d$ were dissociated from the enzyme by treatment with SDS. Between 1 and $1.5 \mathrm{mg} \mathrm{SDS} \mathrm{(mg} \mathrm{protein)}{ }^{-1}$ was required to effect dissociation, The absorption spectrum of the SDS-treated enzyme on reduction with sulphide showed a single peak at $549 \mathrm{~nm}$ in place of a bifurcated $\alpha$-peak (cytochrome $c$ ), whereas the absorption bands due to reduced cytochrome $d$ were not apparent. When the SDS-treated enzyme was chromatographed on Sephadex G-100, the pink cytochrome $c$ component migrated through the column much faster than did the green cytochrome $d$ (Fig. 6). The $A_{280}$ of these two fractions suggested that the bulk of the protein was associated with cytochrome $c$ fraction.

The oxidized and $\mathrm{Na}_{2} \mathrm{~S}_{2} \mathrm{O}_{4}$-reduced spectra of the separated cytochrome $c$ fraction were similar to those of the cytochrome $c$ of the undissociated enzyme, except that on reduction with $\mathrm{Na}_{2} \mathrm{~S}_{2} \mathrm{O}_{4}$, the bifurcation of the $\alpha$-band at 549 to $554 \mathrm{~nm}$ was not so marked but this became apparent on adding nitrite but not nitrate. This effect was not observed for the T. denitrificans cytochrome $c-551$. 
The cytochrome $d$ of the dissociated enzyme had absorption bands in the oxidized form at 405 and $680 \mathrm{~nm}$ and a shoulder near $480 \mathrm{~nm}$. On reduction with $\mathrm{Na}_{2} \mathrm{~S}_{2} \mathrm{O}_{4}$, two broad bands at 460 and $610 \mathrm{~nm}$ were produced (Fig. 7). Reduced cytochrome $d$ was rapidly oxidized in air.

Remixing cytochromes $c$ and $d$ did not restore either nitrite reductase or oxygen uptake activity.

\section{DISCUSSION}

Nitrite reductase from $T$. denitrificans is associated with membranes and attempts to solubilize it with detergents, lipases and proteolytic enzymes inactivated the enzyme. However, activity was removed from membranes by acetone treatment of the cells. The purified enzyme showed both nitrite reductase and cytochrome oxidase activities, suggesting that, as in other denitrifying bacteria, e.g. Pseudomonas aeruginosa (Yamanaka \& Okunuki, 1963a), Microccocus denitrificans (Lam \& Nicholas, 1969; Newton, 1969), these activities are associated with the same protein which functions with either $\mathrm{NO}_{2}^{-}$or $\mathrm{O}_{2}$ as a terminal electron acceptor. Since in the present investigations the bacteria were grown anaerobically with nitrate, the physiological function of this enzyme was for nitrite reduction. Moreover, the specific activity of nitrite reductase was twice that of cytochrome oxidase.

The difference spectra of purified nitrite reductase from $T$. denitrificans showed typical cytochromes $c$ and $d$ bands. Nitrite reductase from $P$. aeruginosa (Horio et al., 1961), which was initially studied as cytochrome oxidase but was referred to later as nitrite reductase (Yamanaka \& Okunuki, 1974), and those from $M$. denitrificans (Lam \& Nicholas, 1969; Newton, 1969) and Alcaligenes faecalis (Iwasaki \& Matsubara, 1971) also contained haem $c$ and $d$. In the present investigations haem $c$ and $d$ were shown to be in the ratio of $1: 1$ as was also reported for nitrite reductase from $P$. aeruginosa (Horio et al., 1961) and A. faecalis (Iwasaki \& Matsubara, 1971). The molecular weight of the $T$. denitrificans nitrite reductase was 120000 , in agreement with the enzyme from $M$. denitrificans (Newton, 1969) and $P$. aeruginosa (Gudat, Singh \& Wharton, 1973). Values of 90000 and 85000 have also been reported for the $P$. aeruginosa enzyme (Horio et al., 1961; Newton, 1969). As for nitrite reductases from $M$. denitrificans and $P$. aeruginosa, copper was not detected in the purified nitrite reductase from $T$. denitrificans.

Sulphide, the physiological reductant of this enzyme, reduced both cytochromes $c$ and $d$. The sequence of the reduction of the $c d$ complex by sulphide indicated that initially cytochrome $c$ was reduced, followed by the reduction of cytochrome $d$. On adding nitrite to the sulphide-reduced enzyme, cytochrome $d$ was oxidized before cytochrome $c$. Wharton, Gudat \& Gibson (1973) and Shimada \& Orii (1976) observed similar patterns for the reduction of cytochromes $c$ and $d$ of nitrite reductase from $P$. aeruginosa using different electron donors, but the sequence of oxidation of reduced cytochromes by nitrite has not been reported earlier. The more positive redox-potential of cytochrome $d$ than that of cytochrome $c$, reported here, supports the suggested pattern of electron transport.

During the oxidation of reduced cytochromes by $\mathrm{NO}_{2}^{-}$, but not $\mathrm{O}_{2}$, a shoulder appeared in the spectrum at $572 \mathrm{~nm}$. This may be associated with the formation of a complex between the enzyme and the product of nitrite reduction. Yamanaka \& Okunuki $(1963 b)$ have observed a similar spectral change on oxidation of the enzyme with $\mathrm{NO}_{2}^{-}$or on bubbling NO through the reduced enzyme. The effect of NO on the spectrum of a nitrite reductase from $P$. aeruginosa has also been observed by Rowe et al. (1977).

During the purification of nitrite reductase from $T$. denitrificans, cytochrome $c-551$ and cytochrome $c-554$ were isolated. The stimulation of both nitrite reductase and cytochrome oxidase activities by catalytic amounts of cytochrome $c-551$, but not by cytochrome $c-554$ or mammalian cytochrome $c$, indicates that it is an electron carrier linking sulphide to the cytochrome $c d$ complex. This suggestion was further strengthened by the observation that reduced cytochrome $c-551$ acts as a reductant for the purified enzyme with either $\mathrm{NO}_{2}{ }^{-}$or 
$\mathrm{O}_{2}$ as a terminal acceptor and one mole of $\mathrm{NO}_{2}{ }^{-}$or $\mathrm{O}_{2}$ was reduced per mole of cytochrome $c$-551 oxidized. Cytochromes $c$-551 from $M$. denitrificans and $P$. aeruginosa have also been reported to serve as electron donors for nitrite reduction and cytochrome oxidase (Horio et al., 1961; Newton, 1969).

The products of ${ }^{15} \mathrm{NO}_{2}-$ reduction by the purified enzyme were primarily ${ }^{15} \mathrm{NO}$ and ${ }^{15} \mathrm{~N}_{2} \mathrm{O}$. Purified nitrite reductases from $P$. aeruginosa (Walker \& Nicholas, 1961), P. denitrificans (Radcliffe \& Nicholas, 1968), M. denitrificans (Lam \& Nicholas, 1969) and P. perfectomarinus (Cox, Payne \& Dervartanian, 1971) produced only $\mathrm{NO}$ from $\mathrm{NO}_{2}^{-}$. A highly purified nitrite reductase from $A$. faecalis (Matsubara \& Iwasaki, 1972) produced both NO and $\mathrm{N}_{2} \mathrm{O}$ as detected by gas chromatography. It was suggested that this nitrite reductase can reduce $\mathrm{NO}$ to $\mathrm{N}_{2} \mathrm{O}$ in agreement with the results reported here for $T$. denitrificans.

Yamanaka \& Okunuki $(1963 c)$ dissociated the nitrite reductase from $P$. aeruginosa into haem $d$ and protein-containing cytochrome $c$ components by acid-acetone treatment; cytochrome $d$ was extracted into acetone and cytochrome $c$ was precipitated. In the present investigations purified nitrite reductase from $T$. denitrificans was resolved into cytochrome $c$ and haem $d$ by SDS treatment and gel filtration on Sephadex G-100. Neither of these components alone nor when mixed together showed either nitrite reductase or cytochrome oxidase activity. Kijimoto (1968) reported that a cytochrome $d$ fraction, obtained by SDS treatment of a nitrite reductase from $P$. aeruginosa and subsequently separated by sucrose density gradient centrifugation, had nitrite reductase activity. Since this cytochrome $d$ contained appreciable amounts of cytochrome $c$ as well, it is doubtful whether cytochrome $d$ alone can function as a nitrite reductase without the cytochrome $c$ part of the complex.

A possible mechanism for electron transfer for the sulphide-linked nitrite reductase in T. denitrificans is:

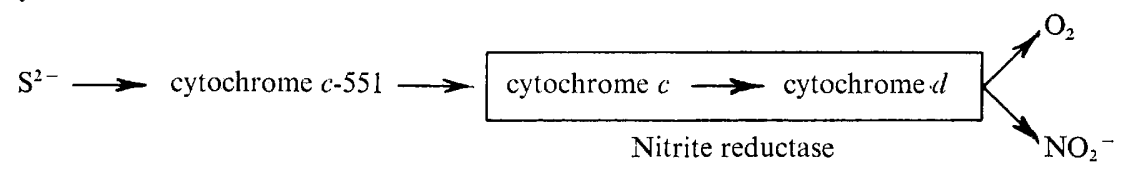

The overall nitrate and nitrite reductases may be represented as follows:

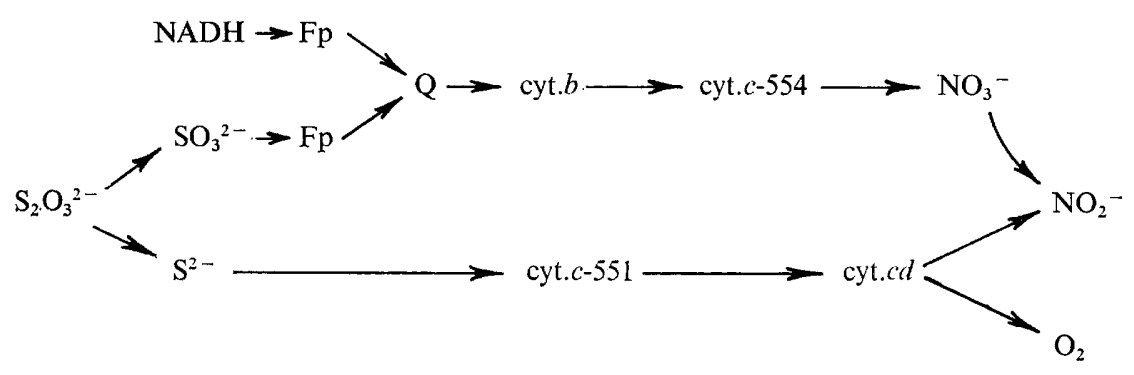

REFERENCES

Adams, C. A., Warnes, G. M. \& Nicholas, D. J. D. (1971). A sulphite-dependent nitrate reductase from Thiobacillus denitrificans. Biochimica et biophysica acta 235, 398-406.

AleEM, M. I. H. (1977). Energy coupling in chemolithotrophic bacteria. Symposia of the Society for General Microbiology 27, 351-381.

AMINUDdIN, M. (1974). Inorganic sulphur compounds oxidation and denitrification in Thiobacillus denitrificans. Ph.D. thesis, University of Adelaide.

Aminuddin, M. \& Nicholas, D. J. D. (1973). Sulphide oxidation linked to the reduction of nitrate and nitrite in Thiobacillus denitrificans.
Biochimica et biophysica acta 325, 81-93.

Aminuddin, M. \& Nicholas, D. J. D. (1974a). Electron transfer during sulphide and sulphite oxidation in Thiobacillus denitrificans. Journal of General Microbiology 82, 115-123.

AminudDin, M. \& Nicholas, D. J. D. (1974b). An AMP-independent sulphite oxidase from Thiobacillus denitrificans: purification and properties. Journal of General Microbiology 82, 103113.

ANDREws, P. (1964). Estimation of molecular weights of proteins by Sephadex gel-filtration. Biochemical Journal 91, 222-233.

MIC 106 
Cox JR, C. D., Payne, W. J. \& Dervartanian, D. V. (1971). Electron paramagnetic resonance studies on the nature of hemoproteins in nitrite and nitric oxide reduction. Biochimica et biophysica acta 253, 290-294.

Gudat, J. C., Singh, J. \& Wharton, D. C. (1973). Cytochrome oxidase from Pseudomonas aeruginosa. 1. Purification and some properties. Biochimica et biophysica acta 292, 376-390.

HewitT, E. J. \& Nicholas, D. J. D. (1964). Enzymes of inorganic nitrogen metabolism. In Modern Methods of Plant Analysis, vol. 7, pp. 67-172. Edited by Y.F. Linskens, B. D. Sanwal and M. V. Tracey. Berlin: Springer Verlag.

Horio, T., Hrgashi, T., Yamanaka, T., Matsubara, H. \& OKUNUKI, K. (1961). Purification and properties of cytochrome oxidase from Pseudomonas aeruginosa. Journal of Biological Chemistry 236, 944-951.

ITZHAKI, R. F. \& Gill, D. M. (1964). A microbiuret method for estimating proteins. Analytical Biochemistry 9, 401-410.

IWASAKI, H. \& MATSUBARA, T. (1971). Cytochrome $c$-557 (551) and cytochrome $c d$ of Alcaligenes faecalis. Journal of Biochemistry 69, 847-857.

Kivimoto, S. (1968). Studies on Pseudomonas cytochrome oxidase. II. Split of Pseudomonas cytochrome oxidase into haem $c$ - and haem $d$ components. Annual Reports of Biological Works, Faculty of Science, Osaka University 16, 19-33.

LAM, Y. \& Nicholas, D. J. D. (1969). A nitrite reductase with cytochrome oxidase activity from Micrococcus denitrificans. Biochimica et biophysica acta 180, 459-472.

MATSUBARA, T. \& IwASAKI, H. (1972). Nitric oxidereducing activity of Alcaligenes faecalis cytochrome $c d$. Journal of Biochemistry 72, 57-64.

NAMBIAR, E. K. S. (1976). Genetic differences in the copper nutrition of cereals. II. Genotypic differences in response to copper in relation to copper, nitrogen and other mineral contents of plants. Australian Journal of Agricultural Research 27, 465-477.

Newton, N. (1969). The two-haem nitrite reductase of Micrococcus denitrificans. Biochimica et biophysica acta 185, 316-331.

PeEters, T. \& Aleem, M. I. H. (1970). Oxidation of sulphur compounds and electron transport in
Thiobacillus denitrificans. Archiv für Mikrobiologie 71, 319-330.

RadCliffe, B. \& Nicholas, D. J. D. (1968). Some properties of a nitrite reductase from Pseudomonas denitrificans. Biochimica et biophysica acta 153, 545-554.

Rowe, J. J., Sherr, B. F., Payne, W. J. \& Eagon, R. G. (1977). A unique nitric oxide-binding complex formed by denitrifying Pseudomonas aeruginosa. Biochemical and Biophysical Research Communications 77, 253-258.

SaWhNEY, V. \& Nicholas, D. J. D. (1977). Sulphiteand NADH-dependent nitrate reductase from Thiobacillus denitrificans. Journal of General Microbiology 100, 49-58.

Shimada, H. \& OrII, Y. (1976). Oxidation-reduction behaviour of the heme $c$ and heme $d$ moieties of Pseudomonas aeruginosa nitrite reductase and formation of oxygenated intermediate at heme $d$. Journal of Biochemistry 80, 135-140.

SQuire, P. G. (1964). A relationship between the molecular weights of macromolecules and their elution volumes based on a model for Sephadex gel filtration. Archives of Biochemistry and Biophysics 107, 471-478.

Walker, G. C. \& Nicholas, D. J. D. (1961). Nitrite reductase from Pseudomonas aeruginosa. Biochimica t biophysica acta 49, 350-360.

Wharton, D. C., Gudat, J. C. \& Gibson, Q. H. (1973). Cytochrome oxidase from Pseudomonas aeruginosa. II. Reaction with copper protein. Biochimica et biophysica acta 292, 611-620.

YAMANAKA, T. \& OKUNUKI, K. (1963a). Crystalline Pseudomonas cytochrome oxidase. I. Enzymic properties with special reference to the biological specificity. Biochimica et biophysica acta 67, 379-393.

YamanAKA, T. \& OKUNUKı, K. (1963b). Crystalline Pseudomonas cytochrome oxidase. II. Spectral properties of the enzyme. Biochimica et biophysica acta 67, 394-406.

YAMANAKA, T. \& OKUNUKI, K. (1963c). Crystalline Pseudomonas cytochrome oxidase. III. Properties of the prosthetic groups. Biochimica et biophysica acta 67, 407-416.

YAMANAKA, T. \& OKUNUKI, K. (1974). Cytochromes. In Microbial Iron Metabolism, pp. 349-400. Edited by J. B. Neilands. New York: Academic Press. 